\title{
Utilization of Renewable Energy: A Study on the Utilization of Solar Energy for Power Plants at the Campus of Universitas Samudra, Indonesia
}

\author{
Hamdani Umar, Munira Amudy, and T. Azuar Rizal
}

\begin{abstract}
The availability of solar energy is higher than global energy consumption, affordable by many users, simple to use, and relatively more environmentally friendly. Complexes of higher education institutions in Indonesia, in general, consist of many buildings with large roofs and stretches of unused land, which are suitable for solar power installations. This study analyzes the feasibility of constructing a solar power plant at an educational institution facility, with a specific case study on the Universitas Samudra campus. The analysis results have shown that for the supply of electricity with a total power of $10 \mathrm{MW}$, PV panels are superior to parabolic collectors. The cost of producing electricity using PV panels is $6.60 \mathrm{c} / \mathrm{kWh}$, while the parabolic collector costs $26.42 \mathrm{c} / \mathrm{kWh}$. And the total area required for the installation of $\mathrm{PV}$ panels is smaller than the use of parabolic collectors.
\end{abstract}

Key words — electricity, land, solar energy, university, utilization.

\section{INTRODUCTION}

Solar power plants are electrical energy generated from the utilization of solar energy. Solar power plants do not produce greenhouse gases and do not release carbon into the air. However, some greenhouse gases are emitted during the construction and transportation of equipment used to build solar power plants. In the range per kilowatt-hour, this greenhouse gas release is minimal compared to the greenhouse gas emissions released during the production of 1 $\mathrm{kWh}$ of electricity from non-renewable energy sources such as coal or natural gas [1].

The attractiveness of using solar energy lies in the fact that the available solar energy is several times higher than global energy consumption. Easy to implement, affordable, and environmentally friendly. According to the United Nations World Development Energy Assessment Report 2000, the annual potential for solar energy is in the range of $1,575^{18}$ $49,837^{18}$ joules. This number is far greater than the total energy consumed worldwide at the beginning of the 21 st century, i.e., $580.5^{18}$ joules [1].

Some researchers believe that solar energy has great potential. V. Smile [2] states that the potential for solar energy is more than $13,368^{18}$ joules per hour. In 2011, the International Energy Agency (IEA) noted that efficient solar energy utilization technologies continue to progress towards

Submitted on July 07, 2021

Published on July 28, 2021.

Hamdani Umar, Mechanical Engineering Department, Engineering

Faculty, Universitas Syiah Kuala, Indonesia.

(e-mail: hamdani@unsyiah.ac.id)

Munira Amudy, Public Relation, Universitas Samudra, Indonesia.

(e-mail: munira ${ }^{@}$ unsam.ac.id) achieving long-term benefits and are expected to increase a country's energy security and make it possible to rely on inexhaustible energy.

The review report on the use of solar energy for thermal energy production states that with the current building construction method, there are some opportunities for solar panels utilization that can provide the building's energy needs. Solar energy will be the primary energy source for buildings in the future. Researchers emphasize the importance of accounting for the use of solar cells in the design and implementation of building construction [3]-[9].

Much literature discusses the technical and economic analysis of renewable energy sources for electricity generation [10]-[13]. Typically, the potential resources for each renewable energy source outweigh the technical, economic, and market potentials. However, it is not enough to assess the cost of investment with the income to be obtained.

Quoting to the International Renewable Energy Agency (IRENA), the cost of normalizing the energy generated by Solar Power Station (SPS) in different countries was varied with an average of $\$ 0,40$ per $1 \mathrm{kWh}$ using the Photovoltaic system (PV) [10], still much more expensive than those produced at power plants using fossil fuels which average $\$ 0.045$ per $1 \mathrm{kWh}$.

Therefore, the construction of large SPS is less in demand because it requires a significant investment. The main advantage of solar energy and other types of renewable energy is its unlimited availability. In most households in villages and small towns, in countries located in sunny areas, even hundreds of square meters of land have been used to install solar panels. The possibility of implementing PV systems in the agricultural sector has also been studied [14][18].

Studies show that solar power plants are less harmful to the environment than other energy sources. Furthermore, the technology provides a positive effect by replacing different types of energy sources. The environmental impact of PV systems on the environment includes impacts on biodiversity, water use, human health, soil and air quality, transport corridors, and land use [12].

Higher education institutions often have many buildings with large roofs and unused expanses of land suitable for

T. Azuar Rizal, Mechanical Engineering Department, Engineering Faculty, Universitas Samudra, Indonesia.

(e-mail: azauarrizal@ ${ }^{@}$ unsam.ac.id). 
solar power installations. Some higher education institutions have started to generate solar power on campus. For example, Monash University in Victoria, Australia, has successfully installed $416 \mathrm{PV}$ panels expected to generate $100,000 \mathrm{kWh}$ of electricity per year [19]. However, this arrangement will soon be defeated by the University of Queensland's planned 1.2 MW photovoltaic array, which will generate $1750 \mathrm{MWh}$ of electricity per year. Harvard University in the United States has also completed the installation of a $500 \mathrm{~kW}$ solar power plant that will produce more than $630,000 \mathrm{kWh}$ per year [20].

In addition, the use of solar power generated on campus serves as a symbol of the university's commitment to the environment. This symbol encourages students, faculty, and staff to take pro-environmental action in daily life. In addition, the use of solar energy by the campus provides a public relations boost to the university, as evidenced by media coverage of institutions that install solar panels. There is often extensive media coverage throughout each alternative energy project's design, installation, and commissioning stages. Furthermore, this will help the university become a better known and respected institution nationally and internationally.

Eventually, solar installations on campus provide valuable teaching and learning opportunities. Universities with solar technology can provide students with direct education on solar energy. In addition, curriculum and training activities can be designed to take advantage of the opportunities provided by having direct access to available solar installations.

The purpose of this study is to research and report on the feasibility and benefits associated with the installation of solar power plant capacity on the Campus of Universitas Samudra (UNSAM). In particular, the study is intended to determine the costs associated with solar power projects on a scale ranging from the provision of $1 \%$ to $100 \%$ of the university's electricity needs.

In addition, the study will investigate which solar power options are most practical for UNSAM. Furthermore, this study will explore the benefits for UNSAM associated with project pursuit, including environmental, financial, learning, teaching, and publicity benefits.

\section{RESEARCH METHODS}

The study was conducted at the UNSAM campus located in Langsa City, Aceh Province, Indonesia. The campus has 48.9 ha or 489,000 square meters, of which 36.6 ha or 366,000 square meters (74.8\%) is currently an undeveloped open space. However, the university has a Master Plan for development until 2045, resulting in the open space area being reduced to approximately $8,313 \mathrm{Ha}$ or 83,130 square meters (17\%). Although this is still a large land area, the open spaces are not always close to each other, and some plots are smaller than 1 hectare.

The campus consists of large buildings that merge in the middle with smaller buildings on the outskirts of the campus (Fig. 1). Most of the open space is located around the campus. Undeveloped land is planned to be developed in the next twenty years.

Solar radiation data is required to calculate the amount of electricity that can be generated from a solar installation. The average solar radiation is the amount of solar radiation that reaches the earth's surface in a given area. Average solar radiation is also known as total solar radiation and is measured in $\mathrm{kWh} / \mathrm{m}^{2} /$ day. By knowing the average daily solar radiation and the peak power rating of solar installations, the electricity generated per day can be calculated.

The First Source, daily solar radiation data, is provided by the United States National Aeronautics and Space Administration (NASA), retrieved from the Surface Meteorology and Solar Energy website.

In this research, the average daily solar radiation data was derived from July 2007 to June 2017. The data is based on the UNSAM position located at north latitude 4.46 and east longitude 97.97 .

The second data source includes several publicly available computer programs with varying degrees of sophistication that can be used to analyze the performance of solar power plants. In this study, the Systems Advisor Model (SAM) computer program was used, allowing the user to consider the inefficiencies associated with solar power installations. The program allows users to choose the type of solar power plant from the various options available, determining the system's power capacity. SAM will generate daily, monthly, and yearly electricity production estimates $(\mathrm{kWh})$. The program will also provide an estimate of land needs for the installation of solar power plant components.

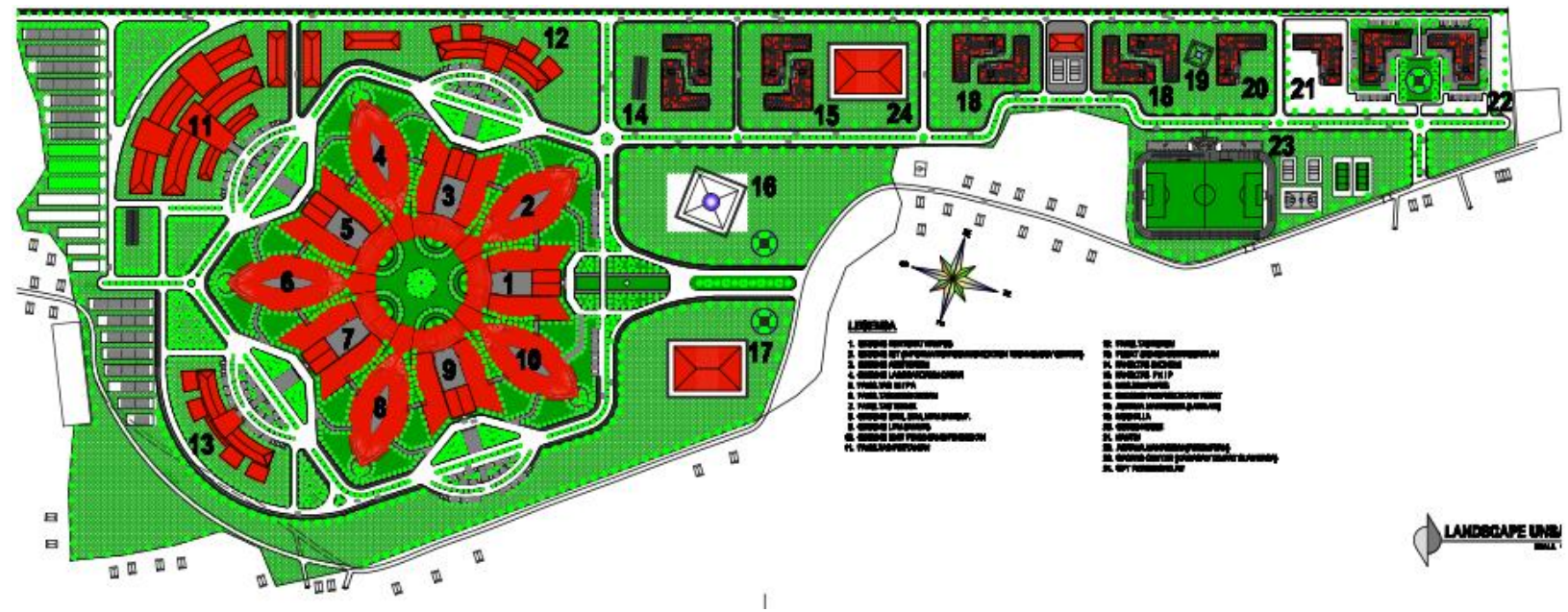

Fig. 1. UNSAM physical development masterplan. 


\section{RESULT AND DISCUSSION}

Based on data records of daily solar radiation average for ten years by NASA (starting from 2007-2017), in areas with latitude coordinates 4.457 and longitude 97.971 , the average radiation every month of the year is as shown in Fig. 1. From the calculation using the average data of daily solar radiation for ten years, obtained the average radiation is $4.46 \mathrm{kWh} / \mathrm{m}^{2} /$ day.

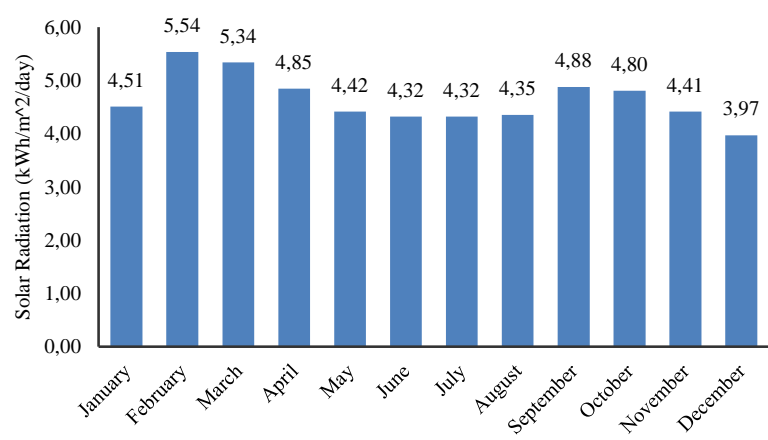

Fig. 2. Monthly solar radiation in a year.

Based on the solar radiation data, using System Advisor Manager (SAM) software, calculating the solar power generation system's total monthly and annual energy production potential is carried out. Calculations will be made for long-term electricity production during 20 years of operation, assuming a $1 \%$ decrease in system performance each year. In this analysis, the calculation of photovoltaic solar power plants and power plants with centralized collectors.

Furthermore, to improve the performance of PV power plants, the PV panel array is equipped with a solar position tracking system. In this study, analysis was conducted for PV arrangement without a tracking system, PV array with 1-axis tracking, and PV array with 2-axis tracking. Table I calculates the result of electricity production calculation for a $1 \mathrm{~kW}$ power PV array. An area required for $1 \mathrm{~kW}$ is $9 \mathrm{~m}^{2}$ [21]. The results of the calculation of energy production from the PV arrangements are shown in Fig. 2.

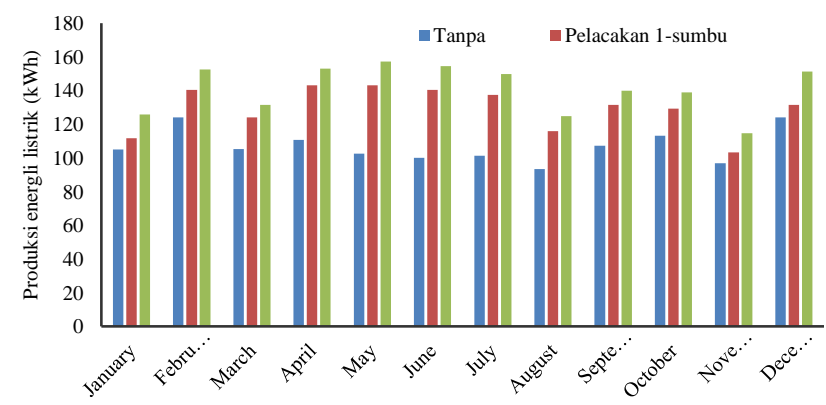

Fig. 3. Annual electricity production of solar power generation systems using PV panels.

Table I provides the calculation of annual electricity production capable of being produced by each photovoltaic array with different power. For PV arrangements, $1 \mathrm{KW}$ without tracking solar position generates annual electricity of 1,281.51 kWh per year, PV arrangements with 1-axis tracking generate annual electricity of $1,551.79 \mathrm{kWh}$ per year, and PV arrangements with 2 -axis tracking generate annual electricity of 1,6,693.54 kWh per year.

Analysis was also conducted to consider the possible use of solar power plants using parabolic collectors. The system consists of a parabolic collector that serves to hold solar energy which is then passed on to heat the working fluid into steam. The steam is then used to drive Stirling engines or move steam turbines. The $25 \mathrm{~kW}$ parabolic collector solar power plant system requires an area of about 90 square meters. Table II calculates the results of the calculation of electricity production produced by the parabolic collector solar power plant system.

TABLE I: ELECTRICITY PRODUCTION OF SOLAR POWER GENERATION SYSTEMS USING PV PANELS

\begin{tabular}{ccccc}
\multicolumn{5}{c}{ SYSTEMS USING PV PANELS } \\
$\begin{array}{c}\text { System } \\
\text { Capacity }\end{array}$ & Tracking & $\begin{array}{c}\text { Annual } \\
\text { Electricity } \\
\text { Production } \\
(\mathrm{kWh})\end{array}$ & $\begin{array}{c}\text { 20 years of } \\
\text { electricity } \\
\text { production } \\
(\mathrm{kWh})\end{array}$ & $\begin{array}{c}\text { Require } \\
\mathrm{d} \text { area } \\
\left(\mathrm{m}^{2}\right)\end{array}$ \\
\hline $1 \mathrm{~kW}$ & Non & 1.284 & 22.855 & 8 \\
$1 \mathrm{KW}$ & 1 axis & 1.552 & 27.626 & 8 \\
$1 \mathrm{~kW}$ & 2 axis & 1.694 & 30.153 & 8 \\
$10 \mathrm{~kW}$ & Non & 12.840 & 228.552 & 80 \\
$10 \mathrm{~kW}$ & 1 axis & 15.520 & 276.256 & 80 \\
$10 \mathrm{~kW}$ & 2 axis & 16.940 & 301.532 & 80 \\
$100 \mathrm{~kW}$ & Non & 128.400 & 2.285 .520 & 800 \\
$100 \mathrm{~kW}$ & 1 axis & 155.200 & 2.762 .560 & 800 \\
$100 \mathrm{~kW}$ & 2 axis & 169.400 & 3.015 .320 & 800 \\
$10000 \mathrm{~kW}$ & Non & 12.827 .920 & 255.147 .329 & 80.000 \\
$10000 \mathrm{~kW}$ & 1 axis & 15.445 .970 & 307.220 .343 & 80.000 \\
$10000 \mathrm{~kW}$ & 2 axis & 16.935 .356 & 336.844 .231 & 800.000 \\
\hline
\end{tabular}

TABLE II: PRODUCTION OF SOLAR POWER GENERATION SYSTEMS USING

\begin{tabular}{ccccc}
\multicolumn{5}{c}{ PARABOLIC COLLECTORS } \\
\hline $\begin{array}{c}\text { System } \\
\text { Capacity }\end{array}$ & $\begin{array}{c}\text { Number of } \\
\text { parabolic } \\
\text { collectors }\end{array}$ & $\begin{array}{c}\text { Annual } \\
\text { Electricity } \\
\text { Production } \\
(\mathrm{kWh})\end{array}$ & $\begin{array}{c}\text { 20 years of } \\
\text { electricity } \\
\text { production } \\
(\mathrm{kWh})\end{array}$ & $\begin{array}{c}\text { Required } \\
\text { area } \\
\left(\mathrm{m}^{2}\right)\end{array}$ \\
\hline $10 \mathrm{~kW}$ & $1 \times 1=1$ & 26.565 & 528.378 & 90 \\
$100 \mathrm{~kW}$ & $2 \times 2=4$ & 96.579 & 1.920 .956 & 360 \\
$225 \mathrm{~kW}$ & $3 \times 3=9$ & 209.580 & 4.168 .546 & 810 \\
$400 \mathrm{~kW}$ & $4 \times 4=16$ & 365.826 & 7.276 .279 & 1440 \\
$625 \mathrm{~kW}$ & $5 \times 5=25$ & 565.362 & 11.245 .050 & 2250 \\
$2500 \mathrm{~kW}$ & $10 \times 10=100$ & 2.213 .189 & 44.020 .329 & 9000 \\
$10000 \mathrm{~kW}$ & $20 \times 20=400$ & 8.762 .275 & 174.281 .650 & 36000 \\
\hline
\end{tabular}

Based on Table I and Table II, for the system capacity of $10000 \mathrm{~kW}(10 \mathrm{MW})$, it was obtained that the production of electricity generated by the two-axis tracking PV panel is still more significant than that of a parabolic collector solar power plant. However, the area required for a parabolic collector solar power plant is minimum compared to $\mathrm{PV}$ with a 2 -axis tracking system. However, judging from system devices requiring Stirling engines or steam turbines, it will undoubtedly require additional costs in its maintenance, so parabolic collector solar power plants are considered unfit for the university.

Analysis of the economic and financial aspects of solar power plants array PV panels and solar power plants collector parabolic Stirling machine is conducted by estimating the cost of power plants using SAM software (System Advisor Model). The comparison of economic analysis results for both solar power plants is shown in Table III. The analysis was conducted for a solar power plant with $10 \mathrm{MW}$ of power. From the table, it can be observed that the cost of electricity production using PV panels is cheaper compared to parabolic 
collectors. The university can consider this cost in the provision of electrical energy in the future.

TABLE III: COMPARISON OF THE RESULTS OF ECONOMIC ANALYSIS OF

\begin{tabular}{|c|c|c|}
\hline Description & 2-Axis PV Panel & Parabolic Collector \\
\hline $\begin{array}{l}\text { Annual energy } \\
\text { (year 1) }\end{array}$ & $16,925,204 \mathrm{kWh}$ & $9,708,744 \mathrm{kWh}$ \\
\hline $\begin{array}{c}\text { Capacity factor } \\
\text { (year } 1)\end{array}$ & $19.3 \%$ & $11.1 \%$ \\
\hline PPA price (year 1 ) & $8.10 \notin / \mathrm{kWh}$ & $32.71 \varnothing / \mathrm{kWh}$ \\
\hline $\begin{array}{l}\text { PPA price } \\
\text { escalation }\end{array}$ & $1.00 \% /$ year & $1.00 \% /$ year \\
\hline $\begin{array}{l}\text { Levelized PPA } \\
\text { price (nominal) }\end{array}$ & $8.75 \notin / \mathrm{kWh}$ & $35.43 \phi / \mathrm{kWh}$ \\
\hline $\begin{array}{l}\text { Levelized PPA } \\
\text { price (real) }\end{array}$ & $6.99 \notin / \mathrm{kWh}$ & $28.13 \phi / \mathrm{kWh}$ \\
\hline $\begin{array}{l}\text { Levelized COE } \\
\quad \text { (nominal) }\end{array}$ & $8.26 \notin / \mathrm{kWh}$ & $33.27 \varnothing / \mathrm{kWh}$ \\
\hline $\begin{array}{l}\text { Levelized COE } \\
\text { (real) }\end{array}$ & $6.60 \notin / \mathrm{kWh}$ & $26.42 \phi / \mathrm{kWh}$ \\
\hline Net present value & $\$ 781,385$ & $\$ 2,042,813$ \\
\hline $\begin{array}{l}\text { Internal rate of } \\
\text { return (IRR) }\end{array}$ & $11.00 \%$ & $11.00 \%$ \\
\hline Net capital cost & $\$ 11,975,404$ & $\$ 32,967,976$ \\
\hline Equity & $\$ 4,964,136$ & $\$ 15,271,329$ \\
\hline Size of debt & $\$ 7,011,268$ & $\$ 17,696,648$ \\
\hline
\end{tabular}

\section{CONCLUSION}

An analysis of the utilization of solar power plants on campus has been conducted with case studies on UNSAM. The results showed that although solar energy could meet up to $42 \%$ of the university's current electricity needs. Analysts' results for power plants using a $1 \mathrm{KW}$ PV panel array without tracking solar position generate $1,281.51 \mathrm{kWh}$ per year while the same system with 1-axis and 2-axis tracking generates annual electricity of $1,551.79 \mathrm{kWh}$ per year, and $1,6,693.54 \mathrm{kWh}$ per year, respectively. Based on the results of the analysis, for the capacity of the system $10000 \mathrm{~kW}$ $(10 \mathrm{MW})$, it was found that the production of electricity produced by 2-axis tracking PV panels is more excellent compared to parabolic collector solar power plants. However, the area required for solar power plants is more diminutive than PV systems.

\section{REFERENCES}

[1] BP, Statistical Review of World Energy, 68th.ed. 2019.

[2] V. Smil, "21th Century Energy Some sobering thoughts," 2006.

[3] R. J. Yang and P. X. W. Zou, "Building integrated photovoltaics (BIPV): Costs, benefits, risks, barriers and improvement strategy," Int. J. Constr. Manag., vol. 16, no. 1, pp. 39-53, 2016.

[4] Y. Sun, "LIFE CYCLE ASSESSMENT OF A NOVEL BUILDING- - INTEGRATED PHOTOVOLTAIC- - - THERMAL ( BIPVT ) SYSTEM," no. January, 2014

[5] R. Pereira, "Design and Optimization of Building Integration PV/T Systems (BIPV/T)," 2015

[6] C. Peng, Y. Huang, and Z. Wu, "Building-integrated photovoltaics (BIPV) in architectural design in China," Energy Build., vol. 43, no. 12, pp. 3592-3598, 2011.

[7] B. Nikolaos and L. Kittima, "Building integrated photovoltaics ( BIPV ) Tools for Implementation and Design Approaches Part 1: Tools for Implementation Part 2: Thesis Report ( Tools for Implementation and Design Approaches )," no. 465, 2012.

[8] S. Strong, "Building Integrated Photovoltaic (BIPV)," 2016. .

[9] B. P. Jelle, C. Breivik, and H. Drolsum Røkenes, "Building integrated photovoltaic products: A state-of-the-art review and future research opportunities," Sol. Energy Mater. Sol. Cells, vol. 100, no. 7465, pp. 69-96, 2012.

[10] A. Juaidi, F. G. Montoya, I. H. Ibrik, and F. Manzano-agugliaro, "An overview of renewable energy potential in Palestine," Renew. Sustain. Energy Rev., vol. 65, pp. 943-960, 2016.

[11] W. E. Alnaser, B. Eliagoubi, A. Al-kalak, and H. Trabelsi, "First solar radiation atlas for the Arab world," Renew. Energy, vol. 29, pp. 1085 1107, 2004.

[12] P. G. Charalambous, G. G. Maidment, S. A. Kalogirou, and K. Yiakoumetti, "Photovoltaic thermal (PV/T) collectors: A review," Appl. Therm. Eng., vol. 27, no. 2-3, pp. 275-286, 2007.

[13] M. G. Gulaliyev, E. R. Mustafayev, and G. Y. Mehdiyeva, "Assessment of Solar Energy Potential and Its Ecological-Economic E ffi ciency: Azerbaijan Case," Sustainability, pp. 1-11, 2020.

[14] A. A. A. Hafez and A. Alblawi, "A feasibility study of PV installation: Case study at Shaqra University," 2018 9th Int. Renew. Energy Congr. IREC 2018, no. Irec, pp. 1-5, 2018

[15] F. Cucchiella, I. D'Adamo, and M. Gastaldi, "Economic analysis of a photovoltaic system: A resource for residential households," Energies, vol. 10, no. 6, pp. 1-15, 2017.

[16] H. A. Kazem, M. H. Albadi, A. H. A. Al-Waeli, A. H. Al-Busaidi, and M. T. Chaichan, "Techno-economic feasibility analysis of $1 \mathrm{MW}$ photovoltaic grid connected system in Oman," Case Stud. Therm. Eng., vol. 10, no. May, pp. 131-141, 2017.

[17] J. Uwibambe, "Design of Photovoltaic System for Rural Electrification in Rwanda," 2017.

[18] L. Lisell and G. Mosey, "Feasibility Study of Economics and Performance of Solar Photovoltaics in Nitro, West Virginia A Study Prepared in Partnership with the Environmental Protection Agency for the RE-Powering America's Land Initiative: Siting Renewable Energy on Potentially Co," Natl. Renew. Energy Lab., vol. Technical, no. August, pp. 1-54, 2010.

[19] B. Bakhiyi, F. Labrèche, and J. Zayed, "The photovoltaic industry on the path to a sustainable future - Environmental and occupational health issues," Environ. Int., vol. 73, pp. 224-234, 2014.

[20] National Wildlife Federation, Harvard University Cambridge, Massachusetts, Solar Photovoltaic Installation. 2010.

[21] F. Ferroni and R. J. Hopkirk, "Energy Return on Energy Invested ( ERoEI ) for photovoltaic solar systems in regions of moderate insolation," Energy Policy, vol. 94, pp. 336-344, 2016. 